\title{
Comparison of Ramosetron with Ondansetron for Prevention of Postoperative Nausea and Vomiting in Patients Undergoing Gynecological Surgery
}

Authors

Abhimanyu Singh $^{1^{*}}$, M Srinaivas ${ }^{2}$, Anu Sai Krishna K.S ${ }^{3}$

${ }^{1 *}$ Associate Professor, ${ }^{2}$ Assistant Professor, ${ }^{3}$ Post Graduate

Department of Anesthesiology, Government Siddhartha Medical College, Vijayawada .

*Corresponding Author

Dr Abhimanyu Singh

Associate professor, Department of Anesthesiology, Government Siddhartha Medical College, Vijayawada, Email:dr.ausingh@gmail.com

\begin{abstract}
Background: Ramosetron is a new selective 5-hydroxytryptamine type $3\left(5 \mathrm{HT}_{3}\right)$ receptor antagonist that reportedly has more potent antiemetic effects compared with other $5 H T_{3}$ receptor antagonists. The purpose of this study was to evaluate the efficacy of Ramosetron for the prevention of postoperative nausea and vomiting (PONV) with that of Ondansetron in patients undergoing gynecological surgery.

Materials and Methods: In this prospective study, 50 healthy patients who were undergoing gynecological operation under general anaesthesia using sevoflurane were enrolled. Patients were divided into two groups: the Ramosetron group (0.3 $\mathrm{mg}$ i.v.; $n=25)$ and the Ondansetron group ( $8 \mathrm{mg}$ i.v.; $n=25)$. The treatments were given 30 minutes before the end of surgery. The incidence of PONV, severity of nausea, and the use of rescue antiemetic requirements during the first $24 \mathrm{~h}$ after surgery were evaluated as two groups (0-6 hours and 6-24 hours).

Results: The incidence of nausea in the first 6 hours after the surgery in the Ramosetron and Ondansetron groups was $4 \%$ \& $20 \%$ respectively, which was statistically insignificant where as late nausea (6-24 hrs) was $12 \%$ and $40 \%$ which was statistically significant. 2 patients in the Ondansetron group and none in the Ramosetron group had vomiting during the first 6 hours, which was statistically insignificant, whereas none in the Ramosetron group and $32 \%$ of patients in Ondansetron group had vomiting during the late postoperative period of 6-24 hours which was statistically significant.

Conclusions: So it was concluded that Ramosetron $0.3 \mathrm{mg}$ i.v. was as effective as Ondansetron $8 \mathrm{mg}$ i.v. in decreasing the incidence of PONV and reducing nausea severity in female patients during the first $6 \mathrm{~h}$ after gynecological surgery but Ramosetron was found to be more effective than Ondansetron in prevention of PONV in the 6-24 hours period after the surgery.

Keywords: Ramosetron, Ondansetron, Nausea, vomiting.
\end{abstract}




\section{INTRODUCTION}

Postoperative nausea and vomiting is one of the most common and distressing side effect encountered by patients following anesthetic and surgical procedures. In the present scenario, it is estimated that 22 to $30 \%$ of adult patients develop postoperative emesis, which is consistently lower when compared to 75 to $80 \%$ reported during the ether era ${ }^{1}$.

As per the literature, incidence of postoperative nausea and vomiting ranges from 25 to $55 \%$ following inpatient surgery and 8 to $47 \%$ for outpatient surgery. When questioned before surgery, it was observed that patients were concerned about postoperative nausea and vomiting apart from pain. Severe and persistent postoperative nausea and vomiting can cause tension on suture lines, bleeding at operative sites and wound dehiscence, venous hypertension, oesophageal tears and rupture, rib fractures, gastric herniation and muscular fatigue. In neurosurgical cases, postoperative nausea and vomiting can cause increased intracranial tension. It can also increase the risk of pulmonary aspiration. It may result in dehydration and electrolyte imbalance in pediatric population ${ }^{2,3,4}$.

Postoperative nausea and vomiting is a major contributor to increase in health care costs for both the hospital and the patient. ${ }^{5}$ These costs may result from longer recovery, extended stay in the hospital, added attention required from nurses and physicians, additional drug supplies as well as unanticipated admissions following outpatient procedures.

Most of the currently used antiemetic drugs like antihistaminics, anticholinergics and dopamine receptor antagonists possess clinically significant side effects. Ramosetron is a new selective 5hydroxytryptamine type $3 \quad\left(5 \mathrm{HT}_{3}\right)$ receptor antagonist that reportedly has more potent antiemetic effects compared with other $5 \mathrm{HT}_{3}$ receptor antagonists ${ }^{6-9}$. The purpose of this study was to evaluate the efficacy of Ramosetron for the prevention of postoperative nausea and vomiting
(PONV) with that of Ondansetron in patients undergoing gynecological surgery.

\section{MATERIAL AND METHODS}

The study was undertaken in the Siddartha Government Medical College and Hospital during a period of 12 months from January 2014to January 2015.A total number of 50 patients in the age group of 26 to 55 years belonging to ASA Grade I and ASA Grade II undergoing gynecological surgery under general anesthesia were selected for the present study. They were randomly divided into two groups, Group A and Group B, each consisting of 25 patients.

Group A received $0.3 \mathrm{mg}$ of Ramosetroni.v and group B received $8 \mathrm{mg}$ of Ondensetroni.v, 30 minutes before the reversal of anesthesia.

Inclusion criteria: Patients of ASA Grades I, and II, Patients between the age group of 26 to 55 years.

Exclusion criteria: Patients belonging to ASA Grade III, IV and V, Patients below the age of 26years, Patients above the age of 55 years, Patients with a history of hypersensitivity to Ondansetron or Ramosetron and those with a history of motion sickness, with recent or chronic ingestion of any other medicine with potential antiemetic properties, with clinically significant cardiovascular, pulmonary, renal, hepatic, neurological or endocrine abnormalities.

The study was approved by the hospital ethics committee and written informed consent was obtained from patients .Preoperative visit was conducted on the previous day of surgery and a detailed history and present complaints were noted. General and systemic examinations of cardiovascular, respiratory and central nervous system were done. Routine laboratory investigations like complete haemogram, blood urea, serum creatinine, and blood sugar, ECG, bleeding time and clotting time were done. Preoperative data collected included age, weight, heart rate, blood pressure, history of motion sickness, previous surgery and PONV. Patients were instructed to remain nil orally after 
$10 \mathrm{PM}$ on the previous night of surgery. Every effort was made to standardize the anesthetic technique. General anesthesia with controlled ventilation was used in all patients. Preoperative pulse rate, blood pressure and peripheral oxygen saturation were recorded in the operation theatre after connecting the following monitors Continuous electrocardiogram, Sphygmomanometer, Pulse oximeter

Peripheral venous access was established and intravenous fluid was started . The patients were premedicated with Inj. Glycopyrrolate $0.004 \mathrm{mg} / \mathrm{kg}$, Inj. Midazolam $0.02 \mathrm{mg} / \mathrm{kg}$, Fentanyl $2 \mathrm{mcg} / \mathrm{kg}$, all through intravenous routes, just before induction as patients were preoxygenated for 3 minutes before induction of anesthesia with Inj. Propofol $2 \mathrm{mg} / \mathrm{kg}$. Inj. Succinylcholine $2 \mathrm{mg} / \mathrm{kg}$ was used as muscle relaxant for intubation with appropriate size endotracheal tube. Inj. Vecuronium $0.08 \mathrm{mg} / \mathrm{kg}$ i.v followed by one fifth of loading dose were used to provide muscle relaxation during surgery

Maintenance of anesthesia was with nitrous oxide $(66 \%)$ and oxygen $(33 \%)$ with Sevoflurane $(0.5-$ $1 \%$ ) using controlled ventilation through closed circuit to maintain an $\mathrm{ETCO}_{2}$ of $30-35 \mathrm{~mm} \mathrm{Hg}$. Patients were monitored during anesthesia using continuous ECG, heart rate, blood pressure, $\mathrm{ETCO}_{2}$ and pulse oximetry. 30 minute before the completion of surgery, antiemetic medication was administered. On completion of surgery, the residual paralysis was reversed with Inj. Neostigmine $0.05 \quad \mathrm{mg} / \mathrm{kg} \quad$ i.v and Glycopyrrolate $0.008 \mathrm{mg} / \mathrm{kg}$ i.v. and after complete recovery patients were extubated.

Patients were transported to the recovery room and later to the ward after confirming an adequate level of consciousness and intact reflexes. The patients were observed for $24 \mathrm{hrs}$ postoperatively for nausea, retching and vomiting. Rescue antiemetics were given if vomiting occurred more than once, for nausea lasting more than 10 minutes or at patient's request. Inj. Diclofenac $1.5 \mathrm{mg} / \mathrm{kg} \mathrm{im}$., were administered to patients who complained of pain.
The incidences of PONV were recorded within the first 24 hours after surgery at intervals of 0-6 hours, and 24 hours. Episodes of PONV were identified by spontaneous complaints by the patients or by direct questioning. Incidence of nausea and vomiting occurring in first six hours is considered as early nausea and vomiting and incidence of PONV after six hours was considered as late emetic episode.

"Complete response" was defined as the absence of nausea, retching or vomiting and no need for rescue antiemetic during the 24-hour observation period. Rescue antiemetic was provided with Inj. Metoclopramide 10mg i.v in the event of 1 or more episodes of vomiting depending on the observer's discretion. We made no distinction between vomiting and retching (ie., retching event was considered a vomiting event). Nausea and vomiting were evaluated on three point ordinal scale. $0=$ none, $1=$ nausea, $2=$ retching or vomiting.

The incidence of nausea and vomiting in the two different groups was analyzed using Chi-square test, $\mathrm{p}<0.05$ was considered significant.

\section{RESULTS}

A total number of 50 cases were taken into study. 25 of them received Ramosetron $0.3 \mathrm{mg}$, and the other 25 patients received Ondansetron $8 \mathrm{mg}$ for preventing postoperative nausea and vomiting through a period of 24 hours. All the patients completed the study. There were no statistically significant differences between the groups with respect to patient characteristics, type of surgery and duration of anesthesia. (Table-1) 
TABLE-1: Demographicand Anesthetic Data

\begin{tabular}{|l|c|c|c|c|c|}
\hline Patient characteristic & $\begin{array}{c}\text { Mean } \\
\text { Group A }\end{array}$ & $\begin{array}{c}\text { Mean } \\
\text { Group B }\end{array}$ & $\begin{array}{c}\text { SD } \\
\text { Group A }\end{array}$ & $\begin{array}{c}\text { SD } \\
\text { Group B }\end{array}$ & P-value \\
\hline Age & 40.52 & 39.84 & 8.70 & 7.44 & $0.2968 \mathrm{NS}$ \\
\hline Weight & 50.3600 & 48.16 & 5.81 & 6.71 & $1.2379 \mathrm{NS}$ \\
\hline $\begin{array}{l}\text { Duration of anesthesia } \\
\text { (min) }\end{array}$ & 100.00 & 89.00 & 26.61 & 14.62 & $1.5454 \mathrm{NS}$ \\
\hline $\begin{array}{l}\text { Duration of surgery } \\
\text { (min) }\end{array}$ & 91.20 & 80.20 & 17.39 & 16.15 & $\mathrm{NS}$ \\
\hline
\end{tabular}

${ }^{*} \mathrm{P}$ value $<0.05$ is significant.

There were no statistically significant differences between the two groups in respect of anesthetic and demographic characteristics.

TABLE-2: Incidence of Nausea

\begin{tabular}{|l|l|l|}
\hline NAUSEA & RAMOSETRON & ONDANSETRON \\
\hline Nausea in first 24 hours of postoperatve period \\
\hline Present & 3 & 12 \\
\hline Absent & 22 & 13 \\
\hline Total & 25 & 25 \\
\hline Early nausea (0-6 hours) & \multicolumn{2}{|l|}{} \\
\hline Present & 1 & 5 \\
\hline Absent & 24 & 20 \\
\hline Total & 25 & 25 \\
\hline Late nausea( $6-24$ hours) & \multicolumn{2}{|l}{} \\
\hline Present & 3 & 10 \\
\hline Absent & 22 & 15 \\
\hline Total & 25 & 25 \\
\hline
\end{tabular}

The incidence of nausea in first 24 hours of postoperative period was significantly high in Group B compared to Group A. Chi Square = 7.8095 , degree of freedom $=1, \mathrm{P}(0.01)=6.63$. (Table value of $\mathrm{X} 2$ at level of significance).

Incidence of early nausea (0-6 hours) in Ramosetron group and Ondansetron groups did not show any statistically significant difference. $(\mathrm{P}$ value >0.05). Chi- square $=3.219$, degree of freedom $=1, \mathrm{P}$ value $(0.05)=3.84$. (Table value of X2 at 0.05 level of significance).

Incidence of late nausea(6-24hours) was $12 \%$ and $40 \%$ inRamosetron and Ondansetron groups respectively, which was statistically significant difference. Chi square $=5.1975$, degree of freedom
$=1, \mathrm{P}$ value $(0.05)=3.84($ Table value of $\mathrm{X} 2$ at 0.05 level of significance.

Incidence of early nausea (0-6 hours) in Ramosetron and Ondansetron were $4 \%$ and $20 \%$ which was statistically insignificant ( $p$ value $>0.05$, table 5) whereas late nausea ( $6-24$ hours) is $12 \%$ and $40 \%$ respectively which was statistically significant. ( $\mathrm{P}$ value $<0.05$, table 6 ). 
TABLE-3: Incidence f Vomiting

\begin{tabular}{|l|l|l|}
\hline VOMITING & RAMOSETRON & ONDANSETRON \\
\hline Vomiting in first 24 hours of postoperative period \\
\hline Present & 0 & 8 \\
\hline Absent & 25 & 17 \\
\hline Total & 25 & 25 \\
\hline Early vomiting (0-6 hours) & 0 & 2 \\
\hline Present & 25 & 23 \\
\hline Absent & 25 & 25 \\
\hline Total & \multicolumn{2}{|l|}{} \\
\hline Late vomiting (6- 24hours) & 0 & 8 \\
\hline Present & 25 & 17 \\
\hline Absent & 25 & 25 \\
\hline Total &
\end{tabular}

Incidence of emetic episodes in 24 hours of postoperative period is significantly high in group B compared to group A $(\mathrm{p}<0.01)$. Chi square = 9.6726, degree of freedom $=1, \mathrm{P}(0.01)=6.63$. (Table value of X2 at 0.01 level of significance) Both Ramosetron and Ondansetron were equally efficacious in preventing vomiting during early postoperative period after recovering from anesthesia ( $\mathrm{p}$ value >0.05). Chi square $=2.602$, degree of freedom $=1, \mathrm{P}$ value $(0.05)=3.84$ (Table value of X2 at 0.05 level of significance).

There were no emetic episodes during 6-24 hours postoperative period in Ramosetron group whereas $32 \%$ of patients in Ondansetron group developed emesis during this late postoperative period, which showed statistically significant difference. Chi square $=9.6726$, degree of freedom $=1, P$ value $(0.05)=6.63$. (Table value of $\mathrm{X} 2$ at 0.05 level of significance).

It was observed that 2 patients in Ondansetron and none in Ramosetron had vomiting during first 6 hours of postoperative period. There was no statistically significant differences between the two groups ( $p>0.05$ Table-7). There were no emetic episodes during 6-24 hours postoperative period in Ramosetron group whereas $32 \%$ of patients in Ondansetron group developed emesis during this late postoperative period, which showed statistically significant difference $(\mathrm{p}<0.05$ )

TABLE-4: Incidence of Postoperative Nausea and Vomiting In First 24 Hours

\begin{tabular}{|l|c|c|}
\hline Postoperative Nausea And Vomiting & Group A (Ramosetron) & Group B (Ondansetron) \\
\hline Present & $3(12 \%)$ & $12(48 \%)$ \\
\hline Absent & $22(88 \%)$ & $13(52 \%)$ \\
\hline Total & 25 & 25 \\
\hline
\end{tabular}

The incidence of postoperative nausea and vomiting in 24 hour period was $12 \%$ and $48 \%$ in Ramosetron and Ondansetron respectively. (Table 2 chi-square $=7.8095, \mathrm{~d} f=1 ; \mathrm{P}(0.01)=6.63)$. The incidence of nausea in first 24 hours of postoperative period was $12 \%$ and $48 \%$ in Ramosetron and Ondansetron respectively. (Table
3 chi-square $=7.8095, \mathrm{~d} f=1 ; \mathrm{P}(0.01)=6.63)$. The incidence of retching/vomiting in first 24 hours postoperative period was $32 \%$ in Ondansetron group and no such episodes occurred with Ramosetron. (Table 4- chi-square = 9.6726; $\mathrm{d} f=1, \mathrm{P}(0.01)=6.63)$. 


\section{DISCUSSION}

Nausea and vomiting following general anesthesia has been a distressing problem for the patients, Inspite of so many advances in the management of postoperative nausea and vomiting with the invention of new drugs, multimodal approaches of management like administering multiple different antiemetic medication, less emetogenic anesthetic techniques, adequate intravenous hydration, adequate pain control, etc., the incidence of postoperative nausea and vomiting remains still high ranging from $25 \%-55 \%$ following inpatient surgery and $8 \%-47 \%$ following outpatient surgery.

In the present study, the antiemetic efficacy of Ondansetron and Ramosetron were assessed in postoperative nausea and vomiting for a period of 24 hours. The postoperative period was again divided into two groups of assessment period (0-6 hrs, early postoperative period and 6-24 hours, late postoperative period) to assess the efficacy of both the drugs during different time intervals. We have selected similar groups of patients in respect of age, weight, duration of surgery and duration of anesthesia to compare the efficacy of the drugs. Analgesia for postoperative pain was standardized and patients of both groups were observed for a period of 24 hours postoperatively. Hence we believe that the difference in postoperative nausea and vomiting is attributed exclusively to the study drugs.

Unlike Kim et al (2009) ${ }^{10}$, we have not included the placebo group in our study for want of approval from hospital ethics committee as the incidence of postoperative nausea and vomiting is very high in our set up without prophylactic antiemetics.Although Ondansetron 4 or $8 \mathrm{mg}$ has been recommended for preventing PONV, the meta-analysis by Ryu et al ${ }^{56}$ suggested that an 8 $\mathrm{mg}$ dose of Ondansetron was optimal for prevention of PONV. Therefore, Ondansetron 8 mg was chosen for this study. According to Ryu et al $^{11}$, Ramosetron is effective in preventing PONV after major gynecological surgery, and Ramosetron $0.3 \mathrm{mg}$ is an effective dose for preventing PONV. In addition, the manufacturer's recommended dose is $0.3 \mathrm{mg}$ i.v. once a day. Therefore, Ramosetron at $0.3 \mathrm{mg}$ dose was chosen for this study.

In October 2009, Kim et al ${ }^{10}$ conducted a study was to evaluate the efficacy of Ramosetron for the prevention of postoperative nausea and vomiting (PONV) with that of Ondansetron or placebo in high-risk patients undergoing gynecological surgery. Like Kim et $\mathrm{al}^{10}$, we did not find any significant differences in the incidence of postoperative nausea and vomiting between the Ramosetron and Ondansetron groups during the first 6 hours after the surgery.

However the incidence of nausea and vomiting in the 6-24 hours postoperative period showed a significant difference with $48 \%$ for Ondansetron group and $12 \%$ for Ramosetron group $(\mathrm{p}<0.01)$, which was unlike that of Kim et al, who did not find a statistically significant difference ( Ramosetron $17 \%$ vs Ondansetron 22\%).In our study, there were no episodes of vomiting in Ramosetron group, where as 8 out of 25 patients in Ondansetron group had vomiting, which was statistically significant. However in the study by Kim et $\mathrm{al}^{10}, 9$ out of 54 patients had emetic episodes in the Ramosetron group and 11 out of 54 patients had emetic episodes in the first 24 hours after surgery, which was not statistically significant.

Kim et $\mathrm{al}^{10}$ reported that 27 out of 54 patients in Ramosetron group had no symptoms of nausea and vomiting, while 30 out of 54 patients receiving Ondansetron had no symptoms of nausea and vomiting. However in our study, 22 out of 25 patients receiving Ramosetron had no symptoms of nausea and vomiting, while only 13 out of 25 patients receiving Ondansetron had no symptoms of nausea and vomiting. So it was concluded that Ramosetron was superior to Ondansetron in the long term prevention of postoperative nausea and vomiting(6- 24 hours) after surgery in the present study, unlike that of the study by Kim et $\mathrm{al}^{54}$. 
In the study by Sarbari et al $^{12}$ to assess the efficacy of Ramosetron, Palonosetron and Ondansetron for preventing postoperative nausea and vomiting in female patients undergoing laparoscopic cholecystectomy, the incidence of postoperative nausea and vomiting was $34.5 \%$, $62.1 \%$ and $65.5 \%$ in the Ramosetron, Palonosetron and Ondansetron groups respectively, representing a significant difference overall ( $\mathrm{p}=0.034)$ as well as between Ramosetron and Ondansetron ( $\mathrm{p}=0.035)$. Ramosetron was labeled to be a better prophylactic antiemetic than Palonosetron or Ondansetron in female patients under general anesthesia. From their study, it was quite obvious that Ramosetron scores significantly over Palonosetron and Ondansetron in its antiemetic properties.

Kim et $\mathrm{al}^{10}$ (2009) compared the frequency of retching and vomiting in adult patients undergoing gynecological surgeries by giving Ondansetron, Ramosetron and placebo in different groups. During 0-6 hours after surgery, the frequencies of retching and vomiting were placebo $31 \%$, Ondansetron $15 \%$ and Ramosetron $6 \%$. Corresponding frequencies during 6-24 hours were placebo $33 \%$, Ondansetron $15 \%$ and Ramosetron $13 \%$. Hence Ramosetron was found to be more superior to Ondansetron or placebo in reducing vomiting but this was not statistically significant. However we found it to be significant statistically in the 6- 24 hour period in our study.

Our study agrees with and confirms the various aspects of the above studies in most of the aspects. We found that Ramosetron has a definite advantage over Ondansetron in the prevention and treatment of postoperative nausea and vomiting in female patients undergoing gynecological surgery under general anesthesia. There was absolutely negligible need for rescue antiemetic medication in Ramosetron group whereas some patients in Ondansetron group needed rescue antiemetic medication in the form of Metoclopramide.

\section{CONCLUSION}

Administration of Ondansetron and Ramosetron 30 minutes before recovery, effectively controlled nausea and vomiting during early postoperative period i.e., within 6 hours after recovery from anesthesia. Postoperative nausea and vomiting in the $6-24$ hours postoperative period after recovering from anesthesia was significantly lower with Ramosetron when compared to Ondansetron. ( $\mathrm{p}$ value <0.01)The administration of Ramosetron 30 minutes before recovery from anesthesia was superior to Ondansetron in long term prevention of postoperative nausea and vomiting following gynecological surgery under general anesthesia.

\section{REFERENCES}

1. Shevde K, Panagopoulos G: A survey of 800 patients knowledge, attitudes, and concerns regarding anesthesia. Anesth Analg 1991; 73:190

2. Andrews PLR. Physiology of nausea and vomiting. Br J Anesth 1992, 69 Suppl 1: 2 - 19.

3. Katzung BG, Master SB, Trevor AJ : basic and clinical pharmacology, 12th edition

4. Kenny GNC. Risk factors for postoperative nausea and vomiting. Br J Anaesth1992; 49 Suppl 1: $6-10$.

5. PA. The big "little problem". AnesthAnalg 1991; 73: 243 - 45.

6. Gan TJ, Meyer T, Apfel CC, et al. Consensus guidelines for managing postoperative nausea and vomiting. AnesthAnalg 2003; 97: 62 - 715

7. Koivuranta M, La“a"ra“ E, Ranta P, Ravaska P, Alahuhta S. Comparison of ondansetron and droperidol in the prevention of postoperative nausea and vomiting after laparoscopic surgery in women. A randomised, double-blind, placebo-controlled trial. Acta Anaesthesiol Scand 1997; 41: 1273 - 96

8. Sadhasivam S, Saxena A, Kathirvel S, Kannan TR, Trikha A, Mohan V. The 
safety and efficacy of prophylactic ondansetron in patients undergoing modified radical mastectomy. AnesthAnalg 1999; 89: 1340 - 57

9. McKenzie R, Kovac A, O’Connor T, et al. Comparison of ondansetron versus placebo to prevent postoperative nausea and vomiting in women undergoing ambulatory gynecologic surgery. Anesthesiology 1993; 78: $21-8$

10. Kim SI, Kim SC, Baek YH, Ok SY, Kim $\mathrm{SH}$,Comparison of Ramosetron with Ondansetron for prevention of postoperative nausea and vomiting in patients undergoing gynecological surgery. Br J Anaesth. 2009 Oct;103(4):549-53.

11. Ryu J, So YM, Hwang J, Do SH, Ramosetron versus Ondansetron for the prevention of postoperative nausea and vomiting after laparoscopic cholecystectomy. Surg Endosc. 2010 Apr;24 (4):812-7.

12. Swailka S, Pal A, Chaterjee S, Saha D, Dawar N. Ondansetron, Ramosetron, or Palonosetron: Which is a better choice of antiemetic to prevent postoperative nausea and vomiting in patients undergoing laparoscopic cholecystectomy?. Anest Essays Res 2011; 182-6 